\title{
Productivity of Poverty. Managing Poverty in Philosophy From Benjamin and Heidegger to Agamben, Negri and Hardt
}

\author{
Szymon Wróbel \\ University of Warsaw, Warsaw, Poland \\ Institute of Philosophy and Sociology of the Polish Academy of Sciences, Warsaw, Poland
}

\begin{abstract}
The main task of the text is to find a new positive formula for "poverty", which instead of addressing it in negative terms - as a threat, degradation, or humiliation - would reveal the potentiality and productivity of poverty. In my text I would like to rethink the status of poverty in four important texts that contribute to the history of 20th century philosophy. My main goal is to understand the philosophical revindication of the categories of "poverty" and "poverty". Who is poor? Who are the poor and do they form a specific class, assemblage, community or collective? What is poverty? Does poverty of the poor regard possession, existence, life, experience, concept, agency, freedom, action? Do these different types of poverty, regarding various fields, have a common denominator? Is seeking poverty worthwhile? Is loyalty to poverty the only imperative of an ethical subject? Is philosophical praise of poverty possible? How, in what language, how can it be praised? In answering these questions, I will turn towards the texts of Benjamin, Heidegger, Agamben, Negri and Hardt.
\end{abstract}

Keywords: biopolitical production, credit, highest poverty, multitude, mob, necessity, proletariat, ragpicker

\section{Question: Who Is Poor?}

Let me begin with a simple confession that philosophy has always had a problem with poverty and the poor. From Plato to Marx, the poor, in the language of philosophy, meant "majority", "mass", "plebs", "mobs", "proletariat" or "lumpen proletariat". Even Marx and Engels in The Communist Manifesto wrote in an indisputable way: "Lumpenproletariat, the social scum, that passively rotting mass thrown off by the lowest layers of the old society, may, here and there, be swept into the movement by a proletarian revolution; its conditions of life, however, prepare it far more for the part of a bribed tool of reactionary intrigue" (Marx \& Engels, 1848/2008, p. 12). Strictly speaking, in Marx, especially in The Eighteenth Brumaire of Louis Bonaparte, we meet two descriptions of the poverty crowd. One is associated with the Society of December 10. It is a crowd that is the political base of Louis Bonaparte - a grotesque mediocrity to play a hero's part. This human population is indeed made up of mobconsisting of

[...] vagabonds, discharged soldiers, discharged jailbirds, escaped galley slaves, swindlers, mountebanks, lazzaroni, pickpockets, tricksters, gamblers, maquereaux[pimps], brothel keepers, porters, literati, organ grinders, ragpickers, knife grinders, tinkers, beggars - in short, the whole indefinite, disintegrated mass, thrown hither and thither, which the French call la bohème. (Marx, 1852/1995, p. 48)

Szymon Wróbel, professor, Institute of Philosophy and Sociology of Polish Academy of Sciences, Faculty of Artes Liberales, University of Warsaw, Warsaw, Poland. 
The second picture of mass is the description of the backroom of the future rebellion and consists of genuinely poor people. Marx turns here mass into numbers, statistics.

To the four million (including children, etc.) officially recognized paupers, vagabonds, criminals, and prostitutes in France must be added another five million who hover on the margin of existence and either have their haunts in the countryside itself or, with their rags and their children, continually desert the countryside for the towns and the towns for the countryside. (Marx, 1852/1995, p. 84)

Here are the new poor of the new affluent world. The question is whether this division and even the split of the masses for "good population" (capable for revolution) and "bad masses" (susceptible to populism and venality) is still valid?

Let us now look at the same problem through the eyes of another philosopher, more conservative. Hannah Arendt, in memorable fragments of The Origins of Totalitarianism regarding the alliance between mob and capital, wrote about "poverty" in categorical and extremely critical categories. For Arendt older than the superfluous wealth was another by-product of capitalist production: the human debris that every crisis eliminated permanently from producing society. According to Arendt men who had become permanently idle were as superfluous to the community as the owners of superfluous wealth. The new fact in the imperialist era is that these two superfluous forces, superfluous capital and superfluous working power, joined hands and left the country together. The author Humane Condition warned:

[...] the mob could not be identified with the growing industrial working class, and certainly not with the people as a whole, but that it was composed actually of the refuse of all classes. This composition made it seem that the mob and its representatives had abolished class differences, that those standing outside the class-divided nation were the people itself (the Volksgemeinschaft, as the Nazis would call it) rather than its distortion and caricature. (Arendt, 1976, p. 196)

Can we imagine more categorical and condemning words directed to "poor mob"? I repeat again: poverty always had a bad reputation within philosophical reason and philosophical discourse.

After these two suggestive examples, I return to my main thesis. Philosophy has sensed that the "majority" must be a "poor majority" as well as an "uneducated majority". Thus, philosophy divided the social world into a "poor majority" and a "small minority" - that of free time, luxury, education, free reading, culture, in a word-an aristocratic minority. Philosophy has sensed that wealth is a prerequisite for education and sovereignty. Perhaps for this reason, philosophy from the very outset had a problem with democracy, which was associated with the "rule of the numerous", "majority rule", where the "majority" had to stay poor and uneducated. This association of poverty, number, democracy understood as the rule of the"numerous" was the primary stigma of philosophical thinking. Philosophy hardly comes out of this misfortune of bad thinking about poverty and democracy. My main thesis for today is the claim that the 20th century philosophy comes out of the misery and to some extent "makes friends" with poverty, "accepts" its scale and inherent deficiency. Perhaps, philosophy in this way finally wants to face the poverty of democracy. I will ask in this text not so much for poverty, but for the contemporary philosophical situation, constellation and even a turn for poverty.

It is Jacques Rancière who discovers the complex relationship between philosophy and poverty. He discovers also the secret relationship between the philosopher and the poor man. Rancière asks a question: what has philosophy to do with the poor? If, as has often been supposed, the poor have no time for philosophy, then why have philosophers always made time for them? Why is the history of philosophy—from Plato and Marx to Sartre and Pierre Bourdieu - the history of so many figures of the poor: plebes, men of iron, the demos, artisans, 
common people, proletarians, lumpen, series, groups in fusion, masses? Philosophy can it ever refrain from thinking for them. Rancière argues that in Marx as much as Plato, the poor comprise in their very exclusion from the vocation of philosopher the condition of philosophical possibility (Rancière, 2004). The poor enable the philosopher to constitute himself - as other than the poor. The question to ask is, however whether The Philosopher and His Poor is, or ever could be, a work of philosophy? Can Rancière speak as a philosopher while exposing the exclusions that constitute philosophy? How can those whose business is not thinking, assume the authority to think and thereby constitute themselves as thinking subjects?

Before we proceed to the next part of the considerations, just one more remark. Michel Foucault claims that the real problem with the poor arose when poverty became an object of police interest. He writes explicitly "[...] vagrants and beggars only become a problem in the countryside at the end of the eighteenth century" (Foucault, 2007 p. 335). In this century, police was thought essentially in terms of what could be called the urbanization of the territory. The birth of the police in the modern sense and the new concept of the poor is closely linked, in Foucault's analysis, to the birth of a new apparatus of security. In the eighteenth century the insecurity of the towns was increased by the influx of the floating population of beggars, vagrants, delinquents, criminals, thieves, murderers who might come from the country. In result towns were allowing for surveillance, since the suppression of city walls made necessary by economic development meant that one could no longer close towns in the evening or closely supervise daily comings and goings. Police and commerce, police and urban development, and police and the development of all the activities of the market, constitute an essential unity in the eighteenth century. Police became than a condition of existence of urban existence. One of the tasks I set for myself in this paper is the question whether it is possible to open the city to beggars, vagrants and poor, in a more radical way? Is it possible to think of poverty beyond of modern security apparatus? In fact I would like to lead the poor, beggars and vagrants, out of the police (Polizeiwissenschaft), beyond the apparatus (dispositif) of security, but not beyond of the city walls.

Philosophy, in "making friends" with poverty, discovers that poverty has more than one name. Therefore, the questions - "who is poor?", and "what makes one poor?"- are of paramount importance. Poor in what regard? Poor, that is, who? Is the philosopher the one who is poor in language and constantly experiences the hunger for language? Is the poet similarly poor in concepts and incessantly experiences the hunger for concepts? Is the proletarian poor in his own means of production and therefore he is accompanied by the hunger for his own production, i.e. craft production? Is the bourgeoisie a class poor in its own work and is therefore constantly in search for a class that would create what it cannot create itself? Man is rich in language and history, but does he not become poor in the experience of the present time? And vice versa: perhaps animals "poor in language" live in the most abundant present. We often forget that even Adam Smith - the author of the monumental book An Inquiry Into the Nature and Causes of the Wealth of Nations spoke more about the richness of human moral feelings than about the economic wealth of nations (Smith, 1776/2008).

Is an insatiable lover-Eros, poor in love, and this is why he always pretends to be Don Juan? There is no total nor homogeneous poverty, and all kinds of wealth are transform into some form of poverty. The tyrant is rich in power and violence, but he is poor in love and appreciation. When Hegel defined man as a being struggling for recognition, he did not suggest anything else than there is this definable being-man, poor is nothing else but recognition, because recognition must be the recognition of the Other instead of one's own imagined recognition? The "thirst for a master", i.e. the desire for "pure prestige" in the dialectic of the master and slave, only exposes the original human poverty. The slave who is poor in appreciation, works for the 
Master to win recognition, and thus impoverish the Master.

This time, however, I would like to rethink the categories of "poverty" from yet a different perspective, i.e. the "beyond-struggle" perspective, beyond the "zero-sum game" in which when one wins, the other loses. The main task of the text is to find a new positive formula for "poverty", which instead of addressing it in negative terms - as a threat, degradation, or humiliation - would reveal the "potentiality" and "productivity". In my text I would like to rethink the status of poverty in four important texts that contribute to the history of 20th century philosophy. My main goal is to understand the philosophical revindication of the categories of "poverty" and "poverty." Who is poor? Who are the poor and do they form a specific class, assemblage, community or collective? What is poverty? Does "poverty of the poor" regard possession, existence, life, experience, concept, agency, freedom, action? Do these different types of poverty, regarding various fields, have a common denominator? Is seeking poverty worthwhile? Is "loyalty to poverty" the only imperative of an ethical subject? Is philosophical praise of poverty possible at all? How, in what language, can it be praised? In answering these questions, I will turn towards the texts of Benjamin, Heidegger, Agamben, Negri and Hardt.

\section{Poverty of Experience (Ragman)}

In his early essay entitled "Experience and Poverty (Erfahrung und Armut)", Walter Benjamin recalls the image of silent people returning from the front of the First World War. Their experience resulted in extreme mutism, speechlessness, speech poverty. Humanity was returning from the battlefield, not richer, but poorer for this experience (Erfahrung). The poverty of experience has brought poverty of speech (stories) and even its withdrawal. It seems that Benjamin wants to generalize the image of poverty by saying that "modern man" is poor not only in experience, but also in speech, the ability to tell stories (Benjamin, 1995). The only alternative to experience and story, in the case of a modern subject, is the myth of continually starting from the beginning, from the level of zero, from life without experience. Experience here means "past experience", and therefore a kind of "accumulation of experience", which was once known perhaps as "wisdom".

Descartes wishing to destroy knowledge (existing superstitions) for certain (axiomatic) knowledge, Einstein seeking to fund new physics on the theoretical incongruity between Newton's equations, and even Paul Klee designing "theoretical figures" on the drawing board - these are all three figures of the same lack, this very same hunger for speech and poverty of experience, the very same mythology of the beginning. The poverty of experience forces the "new man" to start over again and initiate a new beginning. The modern subject self-imposes the "barbaric productivity of poverty", which prepares the conditions for a new common world of the poor in experience and speech. One should consider why Benjamin speaks of "barbaric productivity" and not simply of "productivity" of poverty.

Perhaps Benjamin's "poverty of experience" should not be naively understood as a longing for a new experience. Perhaps Benjamin writes rather about people longing to free themselves from experience, longing for the environment in which they will be able to "realize their poverty" without any hindrance. Perhaps humanity only longs to stop pretending to be rich, also rich in new experiences. In the text from 1928 entitled "One Way Street (Einbahnstraße)"-book-assembly of short, often enigmatic feuilletons, sentences and aphorisms-Benjamin returns to the subject of "naked misery", revealed in the city and the former "poverty that does not disgrace". Benjamin writes: "When there was work that fed a man, there was also poverty that did not disgrace him, if it arose from deformity or other misfortune" (Benjamin, 1985, p. 19). Benjamin surprisingly and unexpectedly calls us to "avoid rapacious gestures". According to Benjamin, man is poor by 
definition, because he is unable to offer the world anything from his own resources. Man is a "dependent being" in the sense that he constantly requires support of the "external forces" offered by the magnanimity of the world, namely, fate or love. However, this raises a certain ethical requirement.

According to Benjamin, man should display respect "in taking": from everything he accepts from time to time, he should return some part before he even recognizes his possession in what is common, what is not his own, what is not private.The pagan prohibition on gathering forgotten ears of corn or fallen grapes serves, according to Benjamin, the earth itself, and it serves to promote the generosity of the world. Benjamin writes sternly:

If society has so degenerated through necessity and greed that it can now receive the gifts of nature only rapaciously, that it snatches the fruit unripe from the trees in order to sell it most profitably, and is compelled to empty each dish in its determination to have enough, the earth will be impoverished and the land yield bad harvests. (Benjamin,1985, p. 24)

Benjamin adds that formerly a beggar at the table enriched each banquet. The splitting up and giving are all-important, not sociable conversation. Benjamin has no doubts: there is a latent connection between the measure of goods and the measure of life: the poorer and scantily filled is the time of life, the more fragile and manifold are its moments.

It is perhaps for this reason, in his monumental unfinished book Passages Baudelaire's ragpicker appears to Benjamin the most provocative figure of human misery. Ragpicker, a scumbag, is this, despised even by Marx, a lumpen proletarian in a double sense of this word is clothed in rags and occupied with rags-someone who wears rags and someone who deals with rags. Ragpicker collects and catalogues everything that the great city has cast off, everything it has lost, and discarded, and broken. Benjamin writes:

He goes through the archives of debauchery, and the jumbled array of refuse. He makes a selection, an intelligent choice; like a miser hoarding treasure, he collects the garbage that will become objects of utility or pleasure when refurbished by Industrial magic. (Benjamin, 2002, p. 387)

The lumpen proletarian nature of a ragpicker is, of course, a form of misery specific to and characteristic of a sated city, a state of constant consumption. It occurs only where life is based on a complex system of satisfying needs, i.e. in a hyper-consumer society. Ragman's misery, wresting from global consumption, is of course a function of waste produced by the city's production system. The "earnings" of the ragman, like those of the worker, are closely related to the condition of the industry, which shares with nature the privilege that it recreates itself from its own waste. Démarche saccadé [abrupt steps] of ragpicker does not need to be the result being drunk; after all, he must stop every now and then to pick up some sort of waste and throw it in his basket. (Benjamin, 2002, p. 404). The walk of the ragpicker is the figure of the modern subject.

\section{Poverty of Existence (Tick)}

Let us now look at the problem of poverty from the perspective of Martin Heidegger's phenomenology. Heidegger in a lecture delivered in June 1945 titled simply "Poverty (Die Armut)" emphasises the element of being, therefore preparing the ground for the ontological reading of poverty (Heidegger, 1994). Poverty has nothing to do with possession, as normal linguistic usage would have it. Poverty is not about "having", but about "being". To be truly poor means to lack nothing but what is not-necessary. Poverty is determined by necessity and thus it is characterised by compulsion. Wealth, giving the privilege of dealing with what is unnecessary, however, gives the appearance of freedom. It is wrong to assume that "lack of necessity" 
guarantees freedom.

The old German word fri, from which freie or free originate, means to "preserve" or "protect", "allow and grant it what belongs to it and what it brings to us". To free something means to guard its essence against all violations of the necessary state. Liberating freedom reverses or transforms necessity. For Heidegger necessity is not the opposite of freedom, but freedom is a "transformed necessity". When we suffer from poverty and desire excess, it is only through our belonging to the order of what is not-necessary. Poor - in this perspective - is a refuge from the excess of what is random or accidental (Heidegger, 1994).

I argue that the problem of "poverty" in Heidegger's philosophy is central. Just as central as the problem of time, death, worldliness, and other notable concepts inhis thinking. Let us remember that according to Heidegger, the real poor in the world are just animals. Animal is, by definition, poor in world and existence. For example Umwelt of tick is reduced to only three carriers of significance: (1) the odour of the butyric acid contained in the sweat of all mammals; (2) the temperature of thirty-seven degrees corresponding to that of the blood of mammals; (3) the typology of skin characteristic of mammals, generally having hair and being supplied with blood vessels. The tick is this relationship; it lives only in its Umwelt and for it.

Poverty of the animal world results from the lack of hands, e.g. a monkey may have organs for capturing things, but no hands. Hands hold the essence of a human being. Man makes himself present not only in what is vorhandene (present) but also in what is zuhandene (handy) - grasping and understanding. Hence the reluctance of Heidegger to technology which creates apparent wealth. For Aristotle, wealth is an abundance of tools, which, however, generate human poverty. A typewriter eliminates all grasping and all understanding. The machine creates a new poverty - the poverty of "being at home and with yourself". The spirit is rich in poverty of machines. In the shortest formula: stone is without a world (weltlos), the animal is poor in the world (weltarm), and man is rich in the world (weltbindend).

For Heidegger, the existence of Dasein is an open negation of indifference, i.e. a wealth of designing one's own possible existence. The fact of being indifferent to its own being characterizes Vorhandensein. Dasein transgresses indifference as a metaphysical and historical phenomenon: it is the lack of the need to ask about being (life). Dasein could not by also "indifferent" to its temporality. "Not getting" means, however, not-being-present. "Lack" understood as "non-being-present" of something that should be present constitutes the definition of being of what is present. In this sense, existence cannot be lacking, not because it is perfect, but because its character is different from any presence. "Human presence" is becoming, and this is possible only in a multitude of projects. The lack of projects of becoming is the only real poverty.

\section{Highest Poverty (Form of Life)}

A philosopher who directly refers to Heidegger and his concept of poverty is Giorgio Agamben. In the famous book The Open. Man and Animal [L'aperto: L' uomo e l'animale] (Agamben, 2004), Agamben returns to Heidegger's lectures titled his course at the University of Freiburg (1929-30) - "The Fundamental Concepts of Metaphysics: World, Finitude, Solitude (Die Grundbegriffe der Metaphysik. Welt-Endlichkeit-Einsamkeit)". These lectures are dedicated first to a broad analysis of "profound boredom" as a fundamental emotional tonality, and then immediately after to an even broader inquiry into the animal's relation with its environment and man's relation with his world. The real subject of these lectures is relationship between the animal's "poverty in world" (Weltarmut) and "world-forming"(weltbildend) man, the origin and sense of that openness which, with man, is produced in the living being (Heidegger, 1938/2001). 
Agamben slightly modifies Heidegger's categorical judgements according to which (1) the stone is worldless [weltlos]; (2) the animal is poor in world [weltarm]; and (3) only man is world-forming [weltbildend]. For Agamben the ontological status of the animal environment can be defined: it is offen (open) but not offenbar - disconcealed openable. For the animal, beings are open but not accessible; that is to say, they are open in an inaccessibility and an opacity-that is, in some way, in a nonrelation. This openness without disconcealment distinguishes the animal's poverty in world from the world-forming which characterizes man. The animal is not simply without world, for insofar as it is open in captivation, it must - unlike the stone, which is worldless - do without world, lack it (entbehren); it can, that is, be defined in its being by a poverty (Agamben, 2004).

In this spirit, transforming the main corpus of Heidegger's concepts, Agamben develops what has to be a provocative genealogy of poverty. His book titled The Highest Poverty, follows the history of thinking and the message of Saint Francis, i.e. the rules of the highest poverty, and in doing so it invites us to rethink the possibilities of their modern use (Agamben, 2013). On the one hand, it depicts the legend of a man "poor by choice", a "new Christ" whose final need was to imitate the Saviour. On the other hand, the book carries out an investigation into the denial of the above rules by institutional and ecclesiastical Christianity. To think poverty with Saint Francis is to think the form of life outside the law and to think bare life, which is never given to anyone as a private property, but instead always appears as what is common, what can be used and shared only in a community of poverty. For Saint Francis one is never poor enough, and demands altissima poverta, the highest poverty. This, however, means renouncing all possessions in order to ultimately reach life of full nakedness.

Agamben writes directly the claim of poverty, which is present in the religion movements between the eleventh and twelfth centuries, is only one aspect of this way or form of life, which strikes observers in a special way. Moreover, it does not represent an ascetic or mortifying practice to obtain salvation as it did in the monastic tradition, but it is now an inseparable and constitutive part of the "apostolic" or "holy" life, which they profess to practice in perfect joy. Perhaps for the first time, what was in question in the movements was not the rule, but the life, not the ability to profess this or that article of faith, but the ability to livein a certain way, to practice joyfully and openly a certain form of life.

In this way Agamben seeks to understand in the exemplary case of Franciscanism not so much the doctrinal, theological, or juridical implications of the form of life claimed by the movements, but rather to interrogate the meaning of the very fact that these claims were put forth essentially on the level of life (Agamben, 2013, p. 45). We will ask ourselves, therefore, first of all if by these terms life, form of life (forma vitae), form of living (forma vivendi) Francis was attempting to name something the sense and novelty of which still remain to be deciphered and which, precisely for this reason, has never ceased to intimately concern us. Franciscanism can be defined - and in this consists its novelty - as the attempt to realize a human life and practice absolutely outside the determinations of the law. Franciscanism, more radically than other contemporary religious movements, can be defined as the invention of a "form of life," that is, of a life that remains inseparable from its form (Agamben, 2013, p. 51).

For us, however, the key question is whether Francis was able to define absolute poverty positively - as a kind of perfect existence, or whether he only defined it negatively, as a kind of lack? At first glance the definition of poverty is purely negative: it is the voluntary abdication of ownership for the Lord's sake, while property is defined technically as the right of dominion, by which someone is said to be lord of something. 
Moreover there follow the definitions of the two ways in which property is acquired according to Roman law: occupation-distinguished according as it refers to someone's goods of property or to things and obligation - which can be mutataor non mutata. Some solution to this problem is the concept of use.

The concept of use is introduced in response to the objection that since natural law prescribes that every person should preserve his or her own nature, one cannot renounce those goods without which this conservation would be impossible. Natural law prescribes that everyone have use of the things necessary to their conservation, but does not obligate them in any way to ownership. Use, being opposed in this way to the right of ownership, is not, however, in any way defined. From Francis' point of view drinking and eating are presented as paradigms of purely factual human practice lacking any juridical implication. The use of consumable goods does not exist in nature and thus cannot belong to anyone. To justify in this case as well the possibility of use, Francis elaborates a true and proper ontology of use, in which being and becoming, existence and time seem to coincide (Agamben, 2013, p. 59).

There remains one doubt. How do we imagine the connection of use with the idea of form of life. It is as if the altissimapaupertas, which was form of life as a perfect life, lost its centrality once it was linked to the concept of ususfacti and ended up being characterized only negatively with respect to the law. Certainly, thanks to the doctrine of use, the Franciscan life could be affirmed unreservedly as that existence which is situated outside the law, which must abdicate the law in order to exist. But what is a life outside the law, if it is defined as that form of life which makes use of things without ever appropriating them? And what is use, if one ceases to define it solely negatively with respect to ownership?

\section{Productive Poverty (Multitude)}

In their following provocative books-Empire, Multitude, Commonwealth and Assembly Michael Hardt and Antonio Negri point out that thinking in terms of poverty will have the positive effect of questioning traditional class determinants, forcing us to anew examine changes in class composition and reconsider wide spectrum of productive activities undertaken both within and outside employment relationship (Hardt \& Negri, 2000; 2009a; 2009b; 2017). From such a perspective, not deficiency but possibility defines poverty. The poor, immigrants, or precarious workers denied permanent employment are often conceived as excluded, but in reality, though subordinated, they exist consistently imbedded within the global rhythms of biopolitical production. In economics, the conditions of existence of the poor are oftentimes recognized only in negative categories, but the same does not apply to life forms, languages, symbols, rituals, tactics, movements or the ability to innovate. This is an important observation regarding the productivity of the poor.

Negri and Hardt's main intention is to lead us out from biopower to biopolitical production. How is this exodus possible at all? let's start with a few explanations. Biopower is a form of power that regulates social life from its interior, following it, interpreting it, absorbing it, and rearticulating it. Power can achieve an effective command over the entire life of the population only when it becomes an integral, vital function that every individual embraces and reactivates of his or her own accord. Biopower thus refers to a situation in which what is directly at stake in power is the production and reproduction of life itself. What is bio-production then? The dominant form of contemporary production creates "immaterial goods" such as ideas, knowledge, forms of communication, and relationships. In such immaterial labor, production spills over beyond the bounds of the economy traditionally conceived to engage culture, society, and politics directly. What is produced in this case is not just material goods but social relationships and forms of life. In bio-capitalism industrial powers produce 
not only commodities but also subjectivities. They produce needs, social relations, bodies, and minds - which is to say, they produce producers. Communication not only expresses but also organizes the movement of production (Hardt \& Negri, 2000; 2009a; 2009b; 2017).

Is a new subject of revolution emerging before our eyes? And is this entity - a multitude? How is the multitude different from the other categories describing the multitude of mop at the head? The concept of the multitude should be contrasted to a series of other concepts that designate plural collectives, such as the crowd, the masses, and the mob. The multitude, designates an active subject, which acts on the basis of what the singularities share in common. The multitude is an internally different, multiple social subject whose constitution and action is based not on identity or unity but on what it has in common. The poor, immigrants, or precarious workers denied permanent employment are often conceived as excluded, but in reality, though subordinated, they exist consistently imbedded within the global rhythms of biopolitical production. In economics, the conditions of existence of the poor are oftentimes recognized only in negative categories, but the same does not apply to life forms, languages, symbols, rituals, tactics, movements or the ability to innovate.

What does this mean for my revolutionary practice? Well that means that revolution is for monsters. You have to lose who you are to discover what you can become. Hardt and Negri do something surprising and paradoxical; they combine revolutionary practicewith reflection on the institutions. To put it schematically, Hardt and Negri try to replace the triad defining modernity: identity/property/sovereignty, with the triad defining alter-modernity: singularity/common good/revolution.

I therefore ask: what is the productivity of poverty today? Where does the postulated "strength of the poor" stem from? In what sense poverty translates into wealth? Is it only that the poor belong to a social class that has nothing to lose? Does the poor create a class of "wage laborers" who, having no means of production, are forced to sell their labour, and therefore have the power to refuse to sell their only strength and in this sense destroy the market? Marx taught that the massive union of workers is not yet the result of their own unification, but the result of the unification of the bourgeoisie.In what sense is the proletariat or precariat a truly revolutionary class?

\section{Planetary Scale Drive-based Society (Calculating Animal)}

In the West, where both in Christian church and ethical thought wealth prevailed, Saint Francis' rules of poverty return as pangs of conscience. Capitalism became a religion, and the most merciless one ever existed, because, as Agamben says quoting Benjamin: "we believe in God and-credit" (Agamben, 1984). Pistis, faith, is the credit that we have with God and which God's word has with us from the moment we started to believe in it. This is why Saint Paul can say in the famous definition that "faith is the substance of things hoped for" (Agamben, 1984).

Let me begin with the statement that from time immemorial all religions, in alliance with sovereign power, tried to manage poverty and exercise power over the poor. Religious logic has postulated that God will reward the poor who accept their state of poverty here on earth. Religion justified poverty. Religion sealed wealth. The doctrine of predestination did it in the manner most cruel and overt at the same time. While the Catholic Church, in consolidating its earthly power, denied that Christ advised poverty and instead emphasized the meaning of Christ the King, the Franciscans categorically declared that poverty is the highest form of spiritual life and that all should practice temperance. The Franciscans maintained not only the necessity of renouncing property, but also the necessity to limit the use of all goods. These are very dangerous declarations for an abundant world. 
The discovery of poverty practices makes this discovery a key political problem. The Franciscans, and also before them - the Cathars, the Waldensians, conducted a critique of property, which was recognized by the powerful as a threat to the power and to the foundation of all the wealth of nations. It has been discovered that when private property is abolished the alliance between religious life (ethics) and sovereign power (politics) will dissipate like fog.

Granted, there is no room for the poor in this world. The relationship between economics, religion and ethics is a central relationship for our civilization. In the Second Essay of On the Genealogy of Morality, Nietzsche develops a quite extraordinary story about the origins and emergence of feelings of responsibility and debt (personal obligation). The principal moral concept of "guilt" (Schuld) descends from the material concept of "debts" (Schulden). "Perhaps our word 'man' (manas)—Nietzsche writes—expresses something of this first sensation of self-confidence: man designated himself as the being who measures values, who values and measures, as the "calculating animal as such"" (Nietzsche, 1887/2007, p. 98). From Nietzsche and Max Weber, through well-known and deservedly known essay of Benjamin Capitalism as Religion, to the study of Philip Goodchild on the genealogy of social insurance and their relationship with banking and religious institutions, a "believer" is simply a person capable to enter into loan agreement (Weber, 1905/1992; Benjamin, 1921/1996; Goodchild, 2002). The world of capital despises those who are too poor to enter into a loan agreement, and too numerous to be destroyed. To be poor is scandalous in the world of universal usury.

Today, i.e. at the dusk of modernity, the new poor are fighting against the alleged wealth of this world produced by capitalism which exploits natural disasters and social crises for capital management. Modern capitalism uses the military doctrine of "shock and awe", i.e. a chronic shock. Contemporary poverty is the time of cataclysm capitalism, in which technology is something which not only enables trauma, but also its exploitation, and dissemination (Klein, 2007; Stiegler, 2015). We are parts of a hyper-consumption, a planetary scale drive-based and "addictogenic society" which also carries out bombing raids on a planetary scale.

Affirmation of poverty and criticism of property should not be understood as deprivation or renunciation, but rather as a new abundance that allows us to avoid a frenzied and thoughtless drive. The Franciscans - recommending a pauper, Walter Benjamin — recommending ragpicker, simply endorse moderate, limited use of goods, avoiding the whims of rampant drive. In terms of materialism, we would say that the affirmation of poverty as abundance is therefore not only indispensable for spiritual transformation, but also for a full life, for life in general. Poverty is not a lack of wealth, but paradoxically its basic prerequisite. It is a very simple message.

Unfortunately, in the capitalist world poverty has become inseparable from exploitation. The poor, like debtors, become slaves. Aristotle called a slave a "living tool". He was right. Marx saw the worker as merely a part attached to the machine. Today, this proletarianization is not just about physical work, but also about mental work. It is primarily concerns working of the brain. Work ability, the work itself - manual ormental, is "absolute poverty". What, at all, is work today-living or dead, mental or physical, work of hands or brain? Who is the employee? What is unpaid work? What is the recognition of the work effect and the recognition of the profession as a job or a vocation? After all, one can work a lot and not be considered an employee. Those who purify the city, direct the air traffic, or deal with the transmission - all leave only virtual traces of their work.

The capitalist construction of poverty reveals a certain truth. Production of wealth and the reproduction of social life are actually in the hands of the poor. Poverty must be combined with power, in the sense that in the capitalist society the "living work" of the workers becomes the possibility of material wealth. It is not the end 
of work understood as the demise of the world's workforce and the beginning of the post-market era is the main destiny of capitalism (Rifkin, 1995), but an excess of invisible work that is a condition for the wealth of people without work. Perhaps the weakness of poor, invisible, not leaving traces, disabled and subordinated allows us to recognize the inevitable dependence of man in general, i.e. his fundamental dependence on others. It is the dependence and the lack of self-sufficiency that we share all. Poverty is not deprivation but a state of wealth and fullness which threatens any sovereign and transcendent power based on possession.

At the end, only one excerpt from Adorno's Minima Moralia, which is an excellent commentary to our story of poverty:

So long as there is still a single beggar, Benjamin writes in a fragment, there is still myth; only with the last beggar's disappearance would myth be appeased. But would not violence then be forgotten as in the child's drowsiness? Would not, in the end, the disappearance of the beggar make good everything that was ever done to him and can never be made good? [...] Would not the beggar, driven out of the gate of civilization, find refuge in his homeland, freed from exile on earth? "Have now peaceful mind, beggar home shall find". (Adorno, 1951/2005, p. 142)

We need another history of poverty. We need another concept and picture of the poor. In the nineteenth century, an example of such an image of poverty was provided by Henry Mayhew. His book London Labor and the London Poor originated in a series of articles for a local newspaper and grew into a massive record of the daily life of Victorian London's underclass (Mayhew, 1851/2010). Mayhew conducted hundreds of interviews that provided a first-hand account of costermongers and street-sellers, of sewer-scavengers and chimney-sweeps, creating an intimate and detailed portrait that offered unprecedented insight into their day-to-day struggle for survival. London Labor and the London Poor exposed a previously hidden world. Will there be a historian in the 21 st century who dares to write a similar history of those absent, invisible people without whom our presence would be impossible?

\section{References}

Adorno, T. W. (1951/2005). Minima moralia. Reflections on a damaged life. E. F. N. Jephcott (Trans.). London: Verso.

Agamben, G. (1984). Se la forecereligione del denarodivorailfuturo. In la Repubblica.it. Credit, Faith and Future. Alvaro, G.-O.

(Trans.). In blogs.publico.qznewz.info. (English)

Agamben, G. (2004). The open: Man and animal. K. Attell (Trans.). Stanford, California.

Agamben, G. (2007). Profanations. J. Fort. (Trans.). New York: Zone Books.

Agamben, G. (2013). The highest poverty: Monastic rules and form-of-life. A. Kotsko (Trans.). Stanford.

Arendt, H. (1976). The origins of totalitarianism. New York: A Harvest Book.

Benjamin, W. (1985). One-way streetand other writings. E. Jephcott \& K. Shorter (Trans.). London: Verso.

Benjamin, W. (1995). Experience and Poverty. In M. R. Trouillot (Ed.), (Benjamin Walter, Selected Writings) Silencing the past: Power and the production of history (vol. 2, pp. 70-107). Boston: Beacon Press.

Benjamin, W. (2002). The arcades project. R. Tiedemann (Ed.), H. Eiland \& K. McLaughlin (Trans.). New York: Belknap Press. Benjamin, W. (1921/1996). Capitalism as religion. In M. Bullock and M. W. Jennings (Eds.), Benjamin Walter, Selected Writings. 1913-1926 (Vol. 1, pp. 288-291). Cambridge, Mass.: Harvard University Press.

Foucault, M. (2007). Security, territory, population: Lectures at the Collège de France, 1977-1978. G. Burchell (Trans.).

Basingstoke: Palgrave Macmillan.

Goodchild, P. (2002). Capitalism and religion: The price of piety. London, New York: Routledge.

Greaney, P. (2008). Untimely beggars. Minneapolis: University of Minnesota Press.

Hardt, M., \& Negri, A. (2000). Empire. Cambridge, Massachusetts \& London, England: Harvard University Press.

Hardt, M., \& Negri, A. (2009a). Commonwealth. Belknap Press of Harvard University Press. 
Hardt, M., \& Negri, A. (2009b). Multitude: War and democracy in the Age of Empire. Penguin Books.

Hardt, M., \& Negri, A. (2017). Assembly. Oxford: Oxford University Press.

Heidegger, M. (1994). Die Armut. In Heidegger Studies, tom 10, Berlin, 5-11.

Heidegger, M. (1938/2001). The fundamental concepts of metaphysics. World, finitude, solitude. W. McNeill \& N. Walker (Trans.). Indiana University Press.

Klein, N. (2007). The shock doctrine. The rise of disaster capitalism. Toronto: Alfred A. Knopf Canada.

Marx, K. (1852/1995). The Eighteenth Brumaire of Louis Bonaparte. New York; Zodiac and Brian Baggins for Marx/Engels Internet Archive.

Marx, K., \& Engels, F. (1848/2008). The manifesto of the Communist Party. London: Pluto Press.

Nietzsche, F. (1887/2007). On the genealogy of morality. A polemic. C. Diethe (Trans.). Cambridge University Press.

Rancière, J. (2004). The philosopher and his poor. A. Parker (Trans.). Durham NC: Duke University Press.

Rifkin, J. (1995). The end of work: The decline of the global labour force and the dawn of the post-market era. Putnam Publishing Group.

Smith, A. (1776/2008). An inquiry into the nature and causes of the wealth of nations: A selected edition. K. Sutherland, (Ed.). Oxford, UK: Oxford Paperbacks.

Stiegler, B. (2015). States of shock. Stupidity and knowledge in the twenty-first century. D. Ross (Trans.). Polity Press.

Weber, M. (1905/1992). The protestant ethic and the spirit of capitalism. T. Parsons (Trans.). London: Routledge. 